\title{
Pengawasan Pemerintah Daerah terhadap Limbah Usaha Batik di Kota Jambi
}

\author{
Mhd Ansori ${ }^{1}$, Nuraini ${ }^{2}$ \\ Fakultas Hukum Universitas Batanghari \\ Jalan Slamet Riyadi Broni Kota Jambi Telp: (0741) 65351 \\ Correspondence email: mhd.ansori@unbari.ac.id
}

\begin{abstract}
Abstrak. Industri besar, menegah dan kecil telah berkembang si kota Jambi. Salah satunya adalah batik tekstil dengan industri pola tradisional yang unik. Industri batik ini tidak luput dari pengawasan Dinas Lingkungan Hidup Kota Jambi terutama terkait limbah batik. Pemerintah daerah dalam menjalankan tugasnya di bantu oleh dinas/badan, kemudian dibentuk peraturan daerah untuk menjalankan pemerintahan daerah. Pemerintah Kota Jambi melalui Dinas Lingkungan Hidup Kota Jambi sebagai Dinas yang bertanggungjawab terhadap pengelolaan lingkungan hidup, telah melakukan berbagai upaya pengelolaan dan pengendalian lingkungan hidup yang dilakukan setiap tahunnya secara langsung ataupun tidak langsung. Pengawasan oleh Dinas Lingkungan Hidup Kota Jambi terhadap usaha batik di Kota Jambi, pengawasan adalah upaya untuk menghindari terjadinya kekeliruankekeliruan, baik disengaja maupun tidak disengaja, sebagai usaha itu preventif, atau juga untuk memperbaikinya apabila sudah terjadi kekeliruan itu, sebagai usaha represif. Tulisan ini bertujuan untuk mengetahui dan menganalisis pengawasan pemerintah daerah terhadap limbah batik di kota Jambi. Tipe penelitian yang digunakan adalah penelitian yuridis normatif, penelitian ini menggunakan" pendekatan konseptual, pendekatan perundang-undangan, dan pendekatan sejarah.
\end{abstract}

Kata kunci: Pengawasan, Pemerintah Daerah, Limbah

\begin{abstract}
Large, medium, and small industries have been developed in Jambi City. One of these is a batik - textile with unique traditional pattern - industry. The batik industry is not spared from the supervision of the Jambi City Environment Office, especially related to batik waste. Regional governments in carrying out their duties are assisted by agencies, then regional regulations are formed to carry out regional government. The Government of the City of Jambi through the Office of the Environment of the City of Jambi as the Office responsible for environmental management, has made various efforts to manage and control the environment which is carried out annually directly or indirectly. Schematically, supervision is divided into two types, namely firstly administrative supervision in the form of inherent supervision and functional supervision, and secondly oversight by judicial authority, both civil and administrative. This paper aims to determine and analyze local government supervision of batik waste in the city of Jambi. This type of research used is normative juridical research, this research uses "conceptual approach, legislation approach, and historical approach.
\end{abstract}

Keywords: Supervision, Local Government, Waste

\section{PENDAHULUAN}

Bermacam industri terus berkembang di Kota Jambi selama ini baik berskala besar, menegah dan kecil. Industri ini selain membuka lapangan kerja juga menjadi devisa bagi Kota Jambi, tetapi juga membuka peluang bertambahnya beban pencemaran, sebagaimana hasil analisa kualitas air Sungai Batanghari yang dilakukan oleh DLH Kota Jambi pada tahun 20 6, memperlihatkan sumber pencemar terdiri dari limbah industri dan limbah domestik, oleh karena itu dibutuhkan cara pengelolaan limbah berwawasan lingkungan sehingga tersedia air dalam jumlah yang cukup serta baik kuantitas dan kualitasnya. ${ }^{1}$

Salah satu industri yang berkembang di sekitar sungai Batanghari adalah industri batik, sebagaimana hasil penelitian Syarifa Mahila. ${ }^{2}$

Bermacam tempat pembuangan limbah cair secara sembarangan, namun yang sering menjadi tempat pembuangan limbah cair adalah sungai, sehingga sungai paling sering tercemar. ${ }^{3}$ Tentunya industri batik ini tidak luput dari pengawasan Dinas Lingkungan Hidup Kota Jambi, sebagaimana yang tertuang dalam Rencana Kerja 209 Dinas Lingkungan Hidup Kota Jambi yang menyatakan bahwa dalam melaksanakan tugas Dinas Lingkungan Hidup Kota Jambi mempunyai fungsi yaitu: a. Perumusan Kebijakan di bidang lingkungan hidup; b. Penyelenggaraan urusan pemerintahan dibidang lingkungan hidup; c. Penataan lingkungan hidup yang meliputi: perencanaan perlindungan dan

\footnotetext{
${ }^{1}$ Erna Rahayu Eko Wiriani dkk, Analisis Kualitas Air Sungai Batanghari Berkelanjutan Di Kota Jambi, Jurnal Pembangunan Berkelanjutan Volume 1. No (1), 2018, Program Magister Ilmu Lingkungan Universitas Jambi, hal.125

${ }^{2}$ Syarifa Mahila, Keberadaan Hak Kekayaan Intelektual Seni Batik Jambi di Kota Jambi, Jurnal Ilmiah Universitas Batanghari Jambi Vol.18 No.3, 2018, LPPM Universitas Batanghari, hal.573

${ }^{3}$ Iys Syabilla Rusda, Pengawasan Pemerintah Daerah Terhadap Pencemaran Limbah Industri Batik Di Kota Pekalongan Pada Tahun 2010-2014, Hal.2
} 
pengelolaan lingkungan hidup dan hal perencanaan kajian lingkungan hidup strategis, kajian dampak suatu lingkungan hidup dan peningkatan kapasitas lingkungan hidup; d. Pengelolaan sampah yang meliputi: pengurangan sampah dan penanganan sampah; e. Pengelolaan limbah berbahaya dan sangat beracun; f. Pengelolaan ruang terbuka hijau meliputi: taman, hutan kota, pohon pelindung dan jalur hijau; g. Pengendalian pencemaran dan kerusakan lingkungan, pemeliharaan lingkungan hidup serta pemantauan lingkungan hidup; h. Penataan lingkungan hidup yang meliputi: penanganan pengaduan dan penyelesaian sengketa lingkungan hidup serta penegakan hukum; i. Pengawasan di bidang lingkungan hidup; j. Penyelenggaraan Unit Pelaksana Teknis (UPT) Dinas Lingkungan Hidup; k. Pelaksana dana dekonsentrasi, tugas pembantuan dan Dana Alokasi Khusus (DAK) bidang lingkungan hidup; 1. Pelaksana program strategis bidang lingkungan hidup antara lain: Adipura, Adiwiyata, SLHD, Proklim, Car Free Day, Mitigasi dan Adaptasi Perubahan Iklim, Langit Biru dan PROPER; dan m. Pelaksanaan tugas lain yang diberikan oleh Walikota sesuai dengan tugas dan fungsinya.

Dalam Rencana Kerja 2019 Dinas Lingkungan Hidup Kota Jambi, mengusung Visi "Terwujudnya Kota Jambi Menjadi Kota Ekologis Sebagai Pusat Perdagangan dan Jasa", diharapkan mewujudkan enam Misi yaitu: 1) Mewujudkan aparatur yang berkualitas didukung oleh sarana dan prasarana yang memadai untuk peningkatan pelayanan masyarakat. 2) Meningkatkan penatan sanitasi kawasan daerah perkotaan. 3) Meningkatkan keseimbangan pembangunan dengan daya dukung dan daya tampung lingkungan. 4) Meningkatkan kinerja dan peran instansi pemerintah dalam perlindungan dan pengelolaan lingkungan hidup. 5) Mewujudkan masyarakat yang peduli dan berbudaya lingkungan dalam perlindungan dan pengelolaan lingkungan hidup. 6) Meningkatkan pembangunan Ruang Terbuka Hijau (RTH) Kota.

\section{Rumusan masalah}

Dari uraian tulisan di atas maka penulis membatasi permasalahan terkait "Bagaimana pengawasan pemerintah daerah terhadap limbah usaha batik di Kota Jambi?"

Teori

Pendapat dari Paulus Efendi Lotulung "pengawasan adalah upaya untuk menghindari terjadinya kekeliruankekeliruan, baik disengaja maupun tidak disengaja, sebagai usaha preventif, atau juga untuk memperbaikinya apabila sudah terjadi kekeliruan itu, sebagai usaha represif". ${ }^{4}$

\section{METODE PENELITIAN}

Dalam tulisan ini tipe penelitiannya adalah penelitian yuridis normatif, atau dengan pendekatan konseptual, pendekatan perundang-undangan"5. Identifikasi bahan hukum secara kritis, logis, dan sistematis, dikumpulkan berdasarkan sistem kartu (card system), "yang memuat sumber yang tepat dari mana catatan itu diambil, informasi atau pendapat yang digunakan, pokok masalah serta kartu yang digunakan adalah kartu kutipan, kartu ulasan, kartu ikhtisar"6. Kemudian dianalisa dengan cara :

1) Menginterpretasikan semua peraturan perundang-undangan sesuai masalah yang dibahas.

2) Menilai bahan-bahan hukum yang berhubungan dengan masalah yang diteliti.

3) Mengevaluasi peraturan perundang-undangan yang berhubungan dengan masalah yang dibahas.

\section{HASIL DAN PEMBAHASAN}

Pemerintah daerah dalam menjalankan tugasnya di bantu oleh dinas/badan, kemudian dibentuk peraturan daerah untuk menjalankan pemerintahan daerah. Pemerintah Kota Jambi melalui Dinas Lingkungan Hidup Kota Jambi sebagai Dinas yang bertanggungjawab terhadap pengelolaan lingkungan hidup, telah melakukan berbagai upaya pengelolaan dan pengendalian lingkungan hidup yang dilakukan setiap tahunnya secara langsung ataupun tidak langsung sebagaimana tertuang didalam Rencana Strategis, penjabaran Rencana Strategis adalah Rencana Kerja (Renja) yang disusun setiap tahun oleh dinas, Rencana Kerja merupakan penghubung antara Renstra dengan perencanaan operasional yang lebih terinci serta merupakan alat untuk monitoring dan evaluasi kinerja, dengan Rencana Kerja Tahunan diupayakan untuk itu mengadakan perencanaan, penataan dan pengendalian lingkungan sehingga pengelolaannya sejalan dengan pelestarian lingkungan. ${ }^{7}$

Dinas Lingkungan Hidup Kota Jambi mempunyai tugas membantu Walikota Jambi dalam melaksanakan penyusunan dan pelaksanaan kebijakan dibidang lingkungan hidup dan tugas perbantuan. Dalam melaksanakan tugas tersebut Dinas Lingkungan Hidup Kota Jambi mempunyai beberapa fungsi yaitu : a. Perumusan Kebijakan di bidang

${ }^{4}$ Paulus Effendie Lotulung dalam Irfan Fachruddin, Pengawasan Peradilan Administrasi Terhadap Tindakan Pemerintah, (Bandung: PT. Alumni, 2004), hlm. 89.

${ }^{5}$ Bahder Johan Nasution, Metode Penelitian Ilmu Hukum, (Bandung: Mandar Maju,2008), hlm. 92.

${ }^{6}$ Ibid, hal. 106.

${ }^{7}$ Rencana Kerja 2019 Dinas Lingkungan Hidup Kota Jambi, Dinas Lingkungan Hidup Kota Jambi, 2018 , hal.2 
lingkungan hidup; b. Penyelenggaraan urusan pemerintahan dibidang lingkungan hidup; c. Penataan lingkungan hidup yang meliputi: perencanaan perlindungan dan pengelolaan lingkungan hidup dan perencanan kajian lingkungan hidup haruslah strategis, kajian dampak lingkungan hidup dan peningkatan kapasitas lingkungan hidup; d. Pengelolaan sampah yang meliputi : pengurangan sampah dan penanganan sampah; e. Pengelolaan suatu limbah berbahaya dan beracun; $\mathrm{f}$. Pengelolaan ruang terbuka hijau meliputi: taman, hutan kota, pohon pelindung dan jalur hijau; g. Pengendalian pencemaran dan kerusakan lingkungan, pemeliharaan lingkungan hidup serta pemantauan lingkungan hidup; $h$. Penaatan sebuah lingkungan hidup yang meliputi : penanganan pengaduan dan penyelesaian sengketa lingkungan hidup serta penegakan hukum; i. Pengawasan di bidang lingkungan hidup; j. Penyelenggaraan Unit Pelaksana Teknis (UPT) Dinas Lingkungan Hidup; k. Pelaksana dana dekonsentrasi, tugas pembantuan dan Dana Alokasi Khusus (DAK) bidang lingkungan hidup; 1. Pelaksana program strategis bidang lingkungan hidup antara lain: Adipura, Adiwiyata, SLHD, Proklim, Car Free Day, Mitigasi dan Adaptasi Perubahan Iklim, Langit Biru dan PROPER; dan m. Pelaksanaan tugas lain yang diberikan oleh Walikota sesuai dengan tugas dan fungsinya.

Kontribusi utama DLH Kota Jambi adalah meningkatkan koordinasi, pengawasan serta kapasitas kelembagaan pengelolaan lingkungan hidup di daerah. Dengan memperhatikan tersebut, maka Visi Dinas Lingkungan Hidup Kota Jambi adalah" Terwujudnya Kota Jambi Menjadi Kota Ekologis Sebagai Pusat Perdagangan dan Jasa”. Untuk dapat mewujudkan Visi Dinas Lingkungan Hidup Kota Jambi trsebut telah ditetapkan misi-misi pembangunan lingkungan hidup seperti berikut: 1. Mewujudkan aparatur yang berkualitas didukung oleh sarana dan prasarana yang memadai untuk peningkatan pelayanan masyarakat. 2. Meningkatkan penataan sanitasi kawasan wilayah perkotaan. 3. Meningkatkan keseimbangan pembangunan itu dengan daya dukung dan daya tampung lingkungan. 4. Meningkatkan kinerja dan peran instansi pemerintah dalam perlindungan dan pengelolaan lingkungan hidup. 5. Mewujudkan masyarakat yang peduli dan berbudaya lingkungan dalam perlindungan dan serta pengelolaan lingkungan hidup. 6 . Meningkatkan pembangunan Ruang Terbuka Hijau (RTH) Kota.

Adapun Sasaran yang akan dicapai sebagai berikut: 1. Meningkatnya adminisrasi perkantoran. 2. Membudayakan hidup bersih dan sehat kepada masyarakat. 3. Meningkatnya pengendalian kerusakan lingkungan hidup. 4. Menurunnya beban pencemaran lingkungan. 5. Meningkatnya hal pengawasan dan penegakan hukum lingkungan hidup. 6. Terintegrasinya rencana kegiatan antar instansi terkait dalam pengelolaan lingkungan hidup. 7. Tersedianya informasi kondisi lingkungan hidup Kota Jambi. 8. Tersedianya kawasan ruang terbuka hijau (RTH) yang representative.

Program merupakan implementasi dari strategi organisasi, yaitu proses penentuan jumlah dan jenis sumber daya yang diperlukan dalam pelaksanaan suatu rencana. Adapun program yang dilaksanakan Dinas Lingkungan Hidup Kota Jambi adalah sebagai berikut: 1. Program Pelayanan Administrasi Perkantoran. 2. Program Peningkatan Sarana dan Prasarana Aparatur. 3. Program Peningkatan Disiplin Aparatur. 4. Program Peningkatan suatu kapasitas Sumber Daya Aparatur. 5. Program Peningkatan Pengembangan Sistem Pelaporan Capaian Kinerja dan Keuangan. 6. Program Suatu Perencanaan SKPD. 7. Program Penurunan Beban Pencemaran. 8. Program Peningkatan Pengelolaan Lingkungan, RTH, Ruang Publik dan juga Kenaekaragaman Hayati. 9. Program Pengendalian Kerusakan Lingkungan dan Pengelolaan Persampahan.

Konsep pengawasan secara garis besar dibedakan menjadi dua macam yaitu: a. Pengawasan preventif, yaitu berupa hak memberikan pengesahan terlebih dahulu terhadap semua keputusan daerah sebelum peraturan daerah dijalankan. b. Pengawasan represif, berupa hak menunda atau membatalkan sesuatu keputusan daerah (yang belum atau sudah berjalan) yang dianggap bertentangan dengan kepentingan umum, undang-undang, peraturan-peraturan yang lebih tinggi tingkatannya. ${ }^{8}$

Pengawasan secara Preventif salah satunya, dengan dibentuknya Peraturan Daerah Kota Jambi Nomor 3 Tahun 2016 Tentang Pengendalian Pencemaran dan juga Kerusakan Lingkungan Hidup, telah ditentukan terkait Pengendalian Kerusakan Lingkungan Hidup, untuk menentukan terjadinya kerusakan lingkungan hidup, ditetapkan kriteria baku kerusakan lingkungan hidup, meliputi kriteria baku kerusakan ekosistem dan kriteria baku kerusakan akibat perubahan iklim yang ditetapkan berdasarkan peraturan perundang-undangan yang berlaku. Tata cara pengukuran kriteria baku kerusakan tanah untuk produksi biomassa meliputi kegiatan entifikasi kondisi awal tanah, analisis sifat dasar tanah, dan evaluasi untuk penetapan status kerusakan tanah yang bertujuan untuk memberikan pedoman bagi Walikota dalam melakukan suatu hal pengukuran kerusakan tanah untuk produksi biomassa kemudian diatur lebih lanjut dlam Peraturan Walikota. Walikota menetapkan sebuah kondisi dan status kerusakan tanah di Kota Jambi berdasarkan hasil pengukuran kriteria baku kerusakan tanah untuk produksi biomassa kemudian diumumkan melalui media massa lokal dan/atau media elektronik dan/atau papan pengumuman dan/atau website.

Kemudian Pengawasan represif adalah pengawasan dengan melakukan penegakan hukum yang bisa memulihkan kembali lingkungan yang mengalami kerusakan melalui tindakan kongkret dalam penerapan sanksi 
terhadap pengusaha batik yang membuang limbah tidak pada tempat yang sudah ditentukan. ${ }^{9}$ Sebagaimana ditentukan dalam Peraturan Daerah Kota Jambi Nomor 3 Tahun 2016 Tentang Pengendalian Pencemaran dan Kerusakan Lingkungan Hidup, telah ditentukan terkait pengawasan dan sanksi administrasi :

Walikota melaksanakan pengawasan terhadap ketaatan penangungjawab usaha dan atau kegiatan atas ketentuan yang ditetapkan dalam peraturan perundang-undangan di bidang pengendalian dan pencemaran lingkungan hidup, hal ini dapat didelegasikan kepada dinas terkait atau yang ditunjuk dan selain itu Walikota wajib menindaklanjuti rekomendasi hasil investigasi DPRD di bidang Lingkungan Hidup, dalam melaksanakan pengawasan, Walikota berhak menetapkan pejabat pengawas lingkungan hidup.

Pejabat pengawas lingkungan hidup berwenang: a. melakukan pemantauan; b. meminta keterangan; c. membuat salinan dari dokumen dan/atau membuat catatan yang diperlukan; d. memasuki tempat tertentu; e. memotret; f. membuat rekaman audio visual; g. mengambil sampel; h. memeriksa peralatan; i. memeriksa instalasi dan/atau alat transportasi; j. menghentikan pelanggaran tertentu, serta dapat melakukan koordinasi dengan pejabat penyidik pegawai negeri sipil, ketentuan lebih lanjut mengenai pengawasan diatur dalam Peraturan Walikota.

Walikota dalam menerapkan sanksi administratif jika ditemukan pelanggaran, dapat menerapkan sanksi yang terdiri dari: a. teguran tertulis; b. paksaan pemerintahan; c. denda administrasi d. pembekuan izin; e. pencabutan izin. Apabila teguran tertulis tidak dilaksanakan, maka dilanjutkan dengan sanksi paksaan pemerintahan dengan biaya dibebankan pada pelanggar. Keterlambatan pelaksanaan paksaan pemerintahan dikenakan denda sebesar Rp. 500.000(lima ratus ribu rupiah) per hari keterlambatan. Apabila paksaan pemerintahan tidak dilaksanakan, maka dilanjutkan dengan pembekuan izin dan atau pencabutan izin. Sanksi administratif tidak melepaskan seseorang atau badan hukum dari suatu gugatan perdata dan tuntutan pidana serta pemulihan lingkungan.

Selain itu ada pula Perda Nomor 7 Tahun 2017 Tentang Pengelolaan dan Pengendalian Limbah Bahan Berbahaya dan Beracun, Walikota itu melakukan Pembinaan yang berguna untuk meningkatkan ketaatan penanggungjawab usaha dan/atau kegiatan dalam pengelolaan limbah B3 dan melakukan Pengawasan untuk melihat bagaimana kondisi pengelolaan limbah B3 dilapangan serta menemukan adanya pelanggaran terkait dengan pengelolaan limbah B3. Pembinaan dan pengawasan yang berkenaan dengan teknis pengendalian limbah B3 dan yang berkenaan dengan pengelolaan administrasi perizinan dilaksanakan oleh perangkat daerah tertentu.

Pembinaan meliputi : a. sosialisasi mengenai peraturan perundang-undangan yang berkaitan dengan pengelolaan limbah B3; b. mendorong upaya reduksi limah B3; c. mendorong upaya penerapan teknologi sesuai perkembangan ilmu dan teknologi; d. menyelenggarakan pelatihan, mengembangkan forum bimbingan dan/atau konsultasi teknis dalam bidang pengelolaan limbah B3; e. menerapan kebijakan insentif dan/atau disentif dengan memberikan sertifikat penghargaan sebagai bukti bahwa pengelolaan limbah B3 dilakukan sesuai ketentuan peraturan perundang-undangan; f. memberikan sertifikat petingatan sebagai bukti bahwa penghasil limbah B3 belum dilakuakan sesuai ketentuan peraturan perundang-undangan.

Pengawasan meliputi: a. persyaratan yang tercantum dalam izin; b. persyaratan teknis pengelolaan limbah B3 bagi usaha dan/atau kegiatan yang tercantum dalam dokumen Amdal atau Upaya Pengelolaan Lingkungan dan Upaya Pemantauan Lingkungan; dan c. ketentuan yang ditetapkan dalam peraturan perundangundangan di bidang perlindungan dan pengeloalaan lingkungan hidup. Pelaksanaan pengawasaan dapat didelegasikan kepada PPLHD yang ditetapkan oleh Walikota atas usul Kepala Dinas Lingkungan Hidup. Ketentuan mengenai tata cara pelaksanaan pembinaan dan pengawasan pengelolaan limbah B3 diatur dengan Peraturan Walikota.

Berdasarkan hasil analisa kualitas air Sungai Batanghari yang dilakukan oleh DLH Kota Jambi pada tahun 2016, diketahui telah melampaui baku mutu yang ditetapkan, hasil analisis tersebut menunjukkan sumber pencemar terindikasi dari limbah industri dan limbah domestik, sehingga diperlukan sebuah strategi pengelolan yang berwawasan lingkungan agar tersedia air dalam jumlah yang aman baik secara kuantitas maupun kualitasnya. ${ }^{10}$

Dalam melakukan pengawasan limbah batik Dinas Lingkungan Hidup Kota Jambi mempunyai fungsi yaitu : a. Perumusan Kebijakan di bidang lingkungan hidup; b. Penyelenggaraan urusan pemerintahan dibidang lingkungan hidup; c. Penataan lingkungan hidup yang meliputi: perencanaan perlindungan dan pengelolaan lingkungan hidup dan perencanaan kajian hal lingkungan hidup strategis, kajian dampak lingkungan hidup dan peningkatan kapasitas lingkungan hidup; d. Pengelolaan sampah yang meliputi : pengurangan sampah dan serta penanganan sampah; e. Pengelolaan limbah berbahaya dan beracun; f. Pengelolaan ruang terbuka hijau meliputi : taman, hutan kota, pohon pelindung dan jalur hijau; g. Pengendalian pencemaran dan kerusakan lingkungan, pemeliharaan lingkungan hidup serta pemantauan lingkungan hidup; h. Penataan lingkungan hidup yang meliputi : penanganan pengaduan dan penyelesaian sengketa lingkungan hidup serta penegakan hukum; i. Pengawasan di bidang lingkungan hidup; j. Penyelenggaraan Unit Pelaksana Teknis (UPT) Dinas Lingkungan Hidup; k. Pelaksana dana dekonsentrasi, tugas pembantuan dan Dana

${ }^{9}$ Iys Syabilla Rusda, Pengawasan Pemerintah Daerah Terhadap Pencemaran Limbah Industri Batik Di Kota Pekalongan Pada Tahun 2010-2014, Hal.8

${ }^{10}$ Erna Rahayu Eko Wiriani, Hutwan yarifudin, Jalius, Analisis Kualitas Air Sungai Batanghari Berkelanjutan Di Kota Jambi, jurnal pembangunan berkelanjutan Volume 1. no (1), Magister Ilmu Lingkungan Universitas Jambi, 2018, hal. 126 
Alokasi Khusus (DAK) bidang lingkungan hidup; 1. Pelaksana program strategis bidang lingkungan hidup antara lain: Adipura, Adiwiyata, SLHD, Proklim, Car Free Day, Mitigasi dan Adaptasi Perubahan Iklim, Langit Biru dan PROPER; dan $m$. Pelaksanaan tugas lain yang diberikan oleh Walikota sesuai dengan tugas dan fungsinya. ${ }^{11}$

Disampaikan oleh Ardi, Kepala Dinas Lingkungan Hidup Kota Jambi bahwa tim terpadu Pemkot Jambi sudah turun langsung melakukan pengecekan limbah B3 kemudian pembinaan dan pengawasan akan terus kami lakukan ${ }^{12}$ sebagaimana telah diberikan peringatan dan pembinaan sejak 2017 lalu terhadap industri kecil, menengah maupun besar tidak boleh langsung membuang limbah mereka harus dilakukan pengelolaan sebelum dibuang. ${ }^{13}$ Hal senada disampaikan Junedi Singarimbun, Ketua Komisi III DPRD Kota Jambi meminta DLH terus intens melakukan pengawasan terhadap limbah industri. ${ }^{14}$

\section{SIMPULAN}

Pemerintah Daerah Kota Jambi telah menerbitkan Peraturan Daerah terkait pengawasan limbah, kemudian ditindaklanjuti melalui Dinas Lingkungan Hidup Kota Jambi melakukan pengawasan terhadap limbah, termasuk limbah batik di Kota Jambi.

\section{Saran}

Semoga pengawasan dilakukan lebih baik lagi agar tercapai lingkungan yang bersih dan sehat.

\section{DAFTAR PUSTAKA}

Bahder Johan Nasution, Metode Penelitian Ilmu Hukum, (Bandung: Mandar Maju,2008

B. N. Marbun. 2005. Otonomi Daerah 1945-2005 Proses dan Realita. Jakarta. Pustaka Sinar Harapan.

Erna Rahayu, Eko Wiriani dkk. 2018. Analisis Kualitas Air Sungai Batanghari Berkelanjutan Di Kota Jambi, Jurnal Pembangunan Berkelanjutan Volume 1. No (1), Program Magister Ilmu Lingkungan Universitas Jambi.

Iys Syabilla Rusda, Pengawasan Pemerintah Daerah Terhadap Pencemaran Limbah Industri Batik Di Kota Pekalongan Pada Tahun 2010-2014.

Jambi-independent.co.id, edisi 25 April 2018 dan 7 Juni 2019

Muchsan, 2007. Sistem Pengawasan Terhadap Perbuatan Aparatur Pemerintah dan Peradilan Tata Usaha Negara di Indonesia, Yogyakarta. Liberty.

Paulus Effendie Lotulung dalam Irfan Fachruddin, 2004. Pengawasan Peradilan Administrasi Terhadap Tindakan Pemerintah, Bandung. PT. Alumni.

Syarifa Mahila. 2018. Keberadaan Hak Kekayaan Intelektual Seni Batik Jambi di Kota Jambi, Jurnal Ilmiah Universitas Batanghari Jambi Vol. 8 No.3, LPPM Universitas Batanghari.

Rencana Kerja 2019 Dinas Lingkungan Hidup Kota Jambi, Dinas Lingkungan Hidup Kota Jambi, 2018.

\footnotetext{
${ }^{11}$ Rencana Kerja 2019 Dinas Lingkungan Hidup Kota Jambi, Dinas Lingkungan Hidup Kota Jambi, 2018.

${ }_{12}$ jambi-independent.co.id edisi 17 Juni 2019, diakses pada 10 April 2020

${ }_{13}$ jambi-independent.co.id edisi 25 April 2018, diakses pada 10 April 2020

${ }^{14}$ jambi-independent.co.id edisi 25 April 2018, diakses pada 10 April 2020
} 